\title{
Morphological variability of Bembidion varium (Coleoptera, Carabidae) in gradient of soil salinity
}

\author{
Viktoriia Komlyk*, Viktor Brygadyrenko
}

Department of Zoology and Ecology, Faculty of Biology and Ecology, Oles’ Honchar Dnipro National University, Dnipro, Gagarin Ave., 72, Dnipro, 49010, Ukraine

\begin{abstract}
Komlyk, V., Brygadyrenko, V., 2020. Morphological variability of Bembidion varium (Coleoptera, Carabidae) in gradient of soil salinity. Folia Oecologica, 47 (1): 23-33.

This article discusses the effect of soil salinity on the variability of Bembidion (Notaphus) varium (Oliver, 1795). The authors of the article collected imagoes of this species in five ecosystems that differed in soil salinity; 13 linear characteristics, one angular characteristic and 6 morphometric indices were measured. Significant changes in six linear parameters of $B$. varium (body length, head length and width, width of prothorax between front angles, maximum width of prothorax and elytra width) and two morphometric indices are observed in the considered ecosystems. Soil salinity probably has the most impact on the variability of these characteristics. However, the influence of other important natural and anthropogenic factors is not ruled out. Significant differences between the sexes are observed for all linear parameters: females of B. varium are larger than males. There are no differences between males and females in morphometric indices. The head width, prothorax length and width, elytra length and width depend on the body length of $B$. varium individuals. The morphological variability of $B$. varium under the influence of other environmental factors needs further research.
\end{abstract}

\section{Keywords}

morphometrics, population variability, riparian beetles, sexual dimorphism

\section{Introduction}

Understanding the patterns of morphological changes and their evolutionary causes is one of the goals of evolutionary biology (PIE and Traniello, 2007). The morphological variability of species is the result of the combined effects of genes and the environment (LUPI et al., 2015; LANGRAF et al., 2017). Insect populations accumulate (summarize) the effects of factor exposure over a certain period of time. Environmental stress can lead to a decrease in metabolic rate, which can be reflected in increased variability of morphological characters (ELEK et al., 2014). At present, it remains unclear at what stage of ontogenesis the influence of environmental factors is the most significant and which of these factors are decisive at a particular case
(Komlyk and Brygadyrenko, 2019b). It is assumed that a change in even one environmental factor is the cause of interpopulation morphological differences in beetles (PALMer, 2002).

Morphological variability within populations is a reflection of the plasticity of the development of a species, and in different populations is a measure of adaptive plasticity of a species (KAWANO, 2006, 2016). There are articles devoted to the influence of the type of food objects (Bonal et al., 2011; MARTYNOV and BryGadyRENKo, 2018; MARTINKOVÁ et al., 2019), the temperature and nature of the substrate (ERNSTING and IsAAKs, 1997), competition (OKUZAKI and Sota, 2018), biogeography (influence of altitude, climate) (SuKhodolskaya and Saveliev, 2016) and anthropogenic factors (VICIAN et al., 2018; SowA

*Corresponding author: 
and SKALSKI, 2019) on the morphological variability of beetles. Little research has been devoted to the influence of environmental factors on the morphological variability of ground beetles (Coleoptera, Carabidae). In previous articles (BRYGADYRENKO, 2015a, 2015b, 2016; BRYGADYRENKO and Korolev, 2015), we examined the influence of various natural and anthropogenic factors in riparian ecosystems on different species of ground beetles, among which the salinity of the soil solution was also analyzed.

Soil salinization is the accumulation of mobile salts in the soil layers above a certain level, which negatively affects the state of the environment. Worldwide, more than 800 million hectares of land are subject to salinization (PICHu, 2016). Soil salinization is intensified by human activities (intensive agriculture and other land use). Soil salinity affects the biotopic distribution of hygrophilous beetles. Many of them prefer saline areas, as they are mostly open, well lit and warm. Soil salinization contributes to the suppression of growth and the ability to infect hosts in fungi pathogenic for ground beetles (DANGALLE et al., 2013). The level of soil salinity affects the duration of developmental stages and phenotypic plasticity of insects (CLARK et al., 2004), as well as the process of laying eggs (SPOMER et al., 2015). We previously examined the effect of soil salinity on Bembidion minimum (Fabricius, 1792) (KomlyK and BrygadyrenKo, 2019b). In this article we want to consider in more detail the effect of soil salinization on the morphological variability of another species of the same subgenus - B. (Notaphus) varium (Oliver, 1795).

Bembidion varium is a Palearctic species that lives on the shores of European water bodies: Albania (Gueorguiev, 2007), England (LufF, 2007), Bulgaria (Jocque et al., 2016), Denmark (Lindroth, 1985), Finland (Lindroth, 1985), France (Petillon et al., 2007), Greece (Hieke and Wrase, 1988), Latvia (Bukejs and Telnov, 2007), Lithuania (TAmUTis et al., 2011), the Republic of Macedonia (Hristovski and Gueorguiev, 2015), the Netherlands (Den Boer, 1970), Norway (Lindroth, 1985), Russia (Caucasus, Siberia) (KRYZHANOvsKiJ et al., 1995), Romania (HieKe and Wrase, 1988), Slovakia (Hurka, 1996), Sweden (Lindroth, 1985), European Turkey (Gueorguiev, 2011), the Czech Republic (KOPECKY, 2007). The species is also common in Dagestan (AbDurakhmanov et al., 2010), Azerbaijan (AtAMEhr, 2013), Egypt (AbDel-Dayem, 1998), Pakistan (Kazi et al., 2016), Turkestan (Gueorguiev and Gueorguiev, 1995) and Mongolia (Lindroth, 1985). Bembidion varium is also found on islands, for example, on the Canary Islands (Gueorguiev and Gueorguiev, 1995). In Ukraine, the species is widespread in the Transcarpathian Lowlands, the Carpathians, Polesye, the broad-leaved forest, foreststeppe and steppe zones (PutchKov, 2012).

The species is hygrophile (SzEnTKIRALYI et al., 2005). It prefers humid clay soils, especially the banks of stagnant water bodies (ZHEREBTSOv, 2000). The species is heliophile, it is active in the daytime, especially in sunny weather (LINDROTH, 1985). It is a halotolerant species (SCHULTZ, 2000), found on both saline and non-saline soils (Lindroth, 1985; Petillon et al., 2007). Bembidion varium is found in bare areas lacking vegetation, as well as with a small number of plants (LINDROTH, 1974; TURIN, 2000) and on salt marshes (LuFF, 2007).

Bembidion varium is a monomorphic macropterous species, characterized by high flight activity of both sexes at the adult stage (Hurka, 1996; Matalin, 2003). The maximum activity in adults is noted in spring and summer (LINDROTH, 1985). Breeding occurs in spring (LINDROTH, 1985). The peak of summer migration is observed in the first half of July, a new generation migrates in search of new biotopes with a stable humid regime (MATALIN, 1998). Bembidion varium often falls into light traps (JoCQUE et al., 2016), and flies more to polarized than to unpolarized light (SzENTKIRALYI et al., 2005). It feeds on nematodes and beetle larvae (Lindroth, 1985). Studies in the Canary Islands revealed that $B$. varium is the host of Laboulbenia vulgaris Peyrit. (Ascomycota) (ARNDT and SANTAMARIA, 2004).

We previously examined the morphological variability of $B$. varium under the influence of anthropogenic factors (SLINKo et al., 2008). The morphological variability of $B$. varium under the influence of natural factors has not yet been studied. The purpose of this article is to evaluate the morphological variability of $B$. varium and to determine which parameters among the linear characteristics and morphometric indices are more variable in the gradient of soil salinity.

\section{Materials and methods}

The research was carried out in five ecosystems in Novomoskovsk, Pokrovka, Pavlograd and Vasilkovka districts of Dnipropetrovsk region of Ukraine (Table 1). The ecosystems differed in mechanical composition, salinity and $\mathrm{pH}$ of the soil, and in the degree of anthropogenic load.

The methodology for determining the total salinity and $\mathrm{pH}$ of the soil is described in our previous article (Brygadyrenko and Slynko, 2015). The $\mathrm{pH}$ of the aqueous extract in all examined areas was weak-alkaline. The salinity of the soil solution varied within $0.37-0.99$ and, in our opinion, is decisive among the influencing factors.

The adults of $B$. varium were collected 10-16 May 2016 (from 10 a.m. to 1 p.m.) manually using an aspirator during pouring water on the soil surface. A total of 107 adults ( 45 males and 62 females) were collected (Table 1). The beetles were frozen during 24 hours in a refrigerating chamber, laid onto cotton mats, straightened in advance of examination (to maintain proportions, we monitored the orientation of the head and prothorax). The dried out insects were photographed through a binocular microscope using a digital camera of 5 megapixels resolution. Each beetle was assigned a serial number, including the ecosystem number and sex of the specimen (female, male). The measurements were performed using digital photographs in the TpsDig 2.17 program.

The following 13 linear characteristics that we have already used before (BRYGADYRENKo and Korolev, 2015) were evaluated: length of body (Lb), head (from 
front edge of clypeus to articulation with prothorax) (Lc), prothorax (Lp), elytra (Le), width of head with eyes (Sc), width of prothorax between front angles (Sp1) and size of the back angles (Sp2), maximum width of prothorax (Sp3), maximum width of elytra (Se), distance from the base of the left and right elytra to the first setae (L11, L1r), distance between setae on the left and right elytra (L21, L2r). The back angles of the prothorax (B) were determined on the right and left parts of the body, for the further calculations their arithmetic mean value was used. Six morphometric indices were calculated: ratio of arithmetic mean value of the width of head, prothorax and elytra to body length $((\mathrm{Sc}+\mathrm{Sp}+\mathrm{Se}) /(3 \mathrm{Lb}))$, ratio of prothorax length to its maximum width $(\mathrm{Lp} / \mathrm{Sp})$, ratio of elytra length to prothorax length (Le/Lp), ratio of maximum width of elytra to maximum prothorax width $(\mathrm{Se} / \mathrm{Sp})$, ratio of prothorax width at the back edge to its maximum width (Sp2/Sp3), and ratio of elytra length to their width (Le/Se).

The results were processed by standard methods using Statistica software (version 8, StatSoft, USA). The effects of sex and ecosystems on morphological characteristics and indices were evaluated using MANOVA. The differences between samples were considered reliable at $\mathrm{P}<0.05$ (taking into account the Bonferroni correction). Variability of morphometric characteristics is represented by Box-Whisker plots. The dependence of morphometric characteristics on body length was evaluated using linear regression analysis. The reliability of the regression equation was estimated by r-square.

\section{Results}

The following results of MANOVA (Table 2) for the morphometric characteristics of the studied $B$. varium populations indicate that the differences between males and females are significant for 13 linear measurements (Lb, Lc, Lp, Le, Sc, Sp1, Sp2, Sp3, Se, L21, L11, L2r and L1r), but they are not significant for angular measurements (the value of the posterior angle of the prothorax B).

The ecosystem condition affects 7 measured characteristics (Lb, Lc, Sc, Sp1, Sp3, Se, L2r). The remaining characteristics (Sp2, Le, Lp, B, L21, L11, L1r) are unchanged in the different ecosystems.

According to the results of MANOVA (Table 3), the habitat conditions significantly affect the ratio of arithmetic mean value of the width of head, prothorax and elytra to body length $(\mathrm{Sc}+\mathrm{Sp}+\mathrm{Se}) /(3 \mathrm{Lb})$ and ratio of elytra length to their width (Le/Se). Sex affects the ratio of maximum width of elytra to maximum prothorax width $(\mathrm{Se} / \mathrm{Sp})$. Sex and ecosystems jointly influence the ratio of prothorax width at the back edge to its maximum width ( $\mathrm{Sp} 2 / \mathrm{Sp} 3)$.

With the increasing salinity of the soil solution (from the first to the fifth sampling area), the differences between males and females of $B$. varium (Figs 1-3) do not change for any of the measured characteristics or for any of the morphometric indices. The linear sizes of $B$. varium individuals within the sexual groups do not have a significant tendency to change within the soil salinity

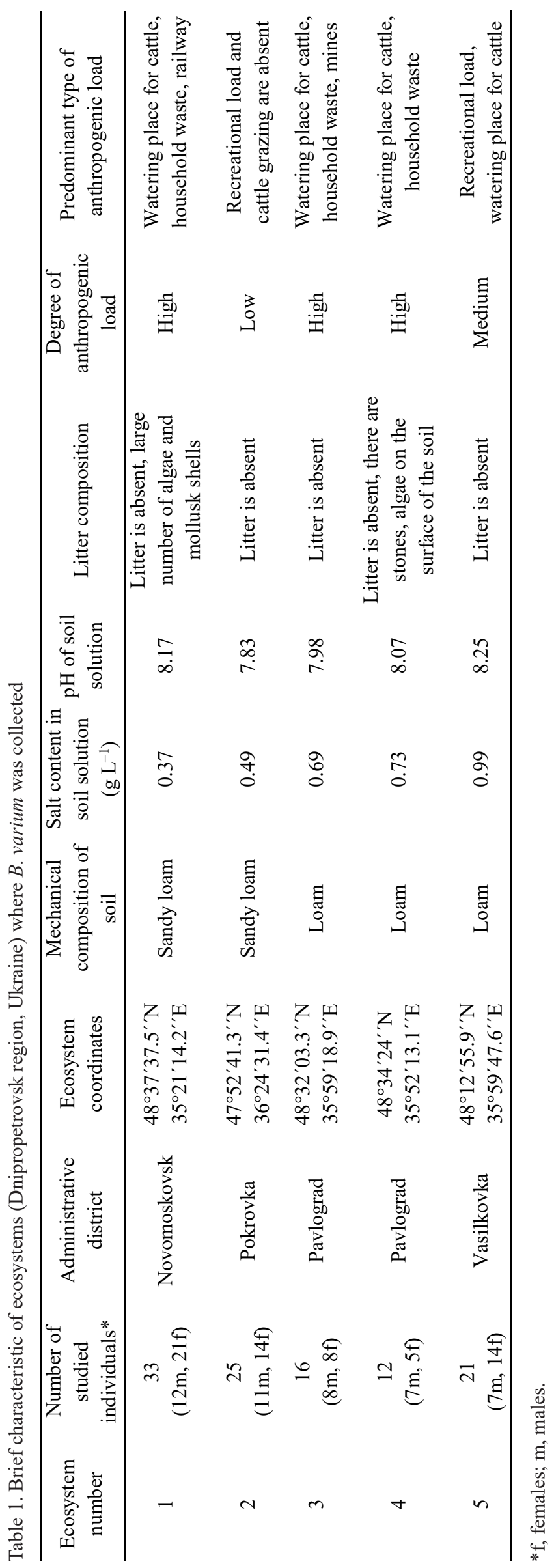


Table 2. MANOVA results for morphometric characteristics of the studied populations of $B$. varium

\begin{tabular}{|c|c|c|c|}
\hline Characteristic & Factor & $F$ & $P$ \\
\hline \multirow{3}{*}{$\mathrm{Lb}$} & Ecosystem & 2.70 & 0.0348 \\
\hline & Sex & 69.87 & $<0.0001$ \\
\hline & Ecosystem * Sex & 1.87 & 0.1215 \\
\hline \multirow{3}{*}{$\mathrm{Lc}$} & Ecosystem & 5.53 & 0.0005 \\
\hline & Sex & 7.65 & 0.0068 \\
\hline & Ecosystem * Sex & 1.69 & 0.1593 \\
\hline \multirow{3}{*}{ Lp } & Ecosystem & 1.80 & 0.1344 \\
\hline & Sex & 46.89 & $<0.0001$ \\
\hline & Ecosystem * Sex & 1.23 & 0.3029 \\
\hline \multirow{3}{*}{$\mathrm{Le}$} & Ecosystem & 0.83 & 0.5089 \\
\hline & Sex & 60.58 & $<0.0001$ \\
\hline & Ecosystem * Sex & 1.37 & 0.2485 \\
\hline \multirow{3}{*}{$\mathrm{Sc}$} & Ecosystem & 4.75 & 0.0015 \\
\hline & Sex & 47.57 & $<0.0001$ \\
\hline & Ecosystem $*$ Sex & 0.37 & 0.8308 \\
\hline \multirow{3}{*}{ Sp1 } & Ecosystem & 3.69 & 0.0077 \\
\hline & Sex & 65.33 & $<0.0001$ \\
\hline & Ecosystem * Sex & 0.34 & 0.8474 \\
\hline \multirow{3}{*}{$\mathrm{Sp} 2$} & Ecosystem & 2.40 & 0.0556 \\
\hline & Sex & 48.92 & $<0.0001$ \\
\hline & Ecosystem $*$ Sex & 1.34 & 0.2608 \\
\hline \multirow{3}{*}{$\mathrm{Sp} 3$} & Ecosystem & 3.13 & 0.0182 \\
\hline & Sex & 46.40 & $<0.0001$ \\
\hline & Ecosystem $*$ Sex & 0.40 & 0.8073 \\
\hline \multirow{3}{*}{$\mathrm{Se}$} & Ecosystem & 4.71 & 0.0016 \\
\hline & Sex & 78.20 & $<0.0001$ \\
\hline & Ecosystem * Sex & 1.10 & 0.3591 \\
\hline \multirow{3}{*}{ B } & Ecosystem & 1.62 & 0.1766 \\
\hline & Sex & 0.21 & 0.6515 \\
\hline & Ecosystem $*$ Sex & 1.79 & 0.1367 \\
\hline \multirow{3}{*}{ L21 } & Ecosystem & 2.25 & 0.0691 \\
\hline & Sex & 6.25 & 0.0141 \\
\hline & Ecosystem * Sex & 0.71 & 0.5889 \\
\hline \multirow{3}{*}{ L11 } & Ecosystem & 1.15 & 0.3371 \\
\hline & Sex & 37.49 & $<0.0001$ \\
\hline & Ecosystem $*$ Sex & 0.97 & 0.4273 \\
\hline \multirow{3}{*}{$\mathrm{L} 2 \mathrm{r}$} & Ecosystem & 3.45 & 0.0112 \\
\hline & Sex & 9.03 & 0.0034 \\
\hline & Ecosystem $*$ Sex & 0.53 & 0.7137 \\
\hline \multirow{3}{*}{ L1r } & Ecosystem & 1.42 & 0.2333 \\
\hline & Sex & 29.77 & $<0.0001$ \\
\hline & Ecosystem $*$ Sex & 2.22 & 0.0725 \\
\hline
\end{tabular}

$\mathrm{Lb}$, length of body; Lc, length of head; Lp, length of prothorax; Le, length of elytra; Sc, width of head with eyes; Sp1, width of prothorax between front angles; Sp2, width of prothorax between back angles; Sp3, maximum width of prothorax; Se, maximum width of elytra; B, back angles of prothorax; L11, distance from the base of the left elytra to the first setae; L1r, distance from the base of the right elytra to the first setae; L21, distance between setae on the left elytra; L2r, distance between setae on the right elytra. 
Table 3. MANOVA results for morphometric indices of the studied populations of B. varium

\begin{tabular}{|c|c|c|c|}
\hline Characteristic & Factor & $F$ & $P$ \\
\hline \multirow{3}{*}{$(\mathrm{Sc}+\mathrm{Sp}+\mathrm{Se}) /(3 \mathrm{Lb})$} & Ecosystem & 4.41 & 0.0028 \\
\hline & Sex & 2.59 & 0.1095 \\
\hline & Ecosystem * Sex & 0.92 & 0.4928 \\
\hline \multirow{3}{*}{$\mathrm{Lp} / \mathrm{Sp}$} & Ecosystem & 0.71 & 0.5883 \\
\hline & Sex & 0.14 & 0.7080 \\
\hline & Ecosystem * Sex & 1.71 & 0.1546 \\
\hline \multirow{3}{*}{$\mathrm{Le} / \mathrm{Lp}$} & Ecosystem & 1.19 & 0.3221 \\
\hline & Sex & 0.14 & 0.7138 \\
\hline & Ecosystem * Sex & 1.54 & 0.1956 \\
\hline \multirow{3}{*}{$\mathrm{Se} / \mathrm{Sp}$} & Ecosystem & 0.24 & 0.9158 \\
\hline & Sex & 4.37 & 0.0392 \\
\hline & Ecosystem * Sex & 1.18 & 0.3252 \\
\hline \multirow{3}{*}{$\mathrm{Sp} 2 / \mathrm{Sp} 3$} & Ecosystem & 2.21 & 0.0741 \\
\hline & Sex & 0.39 & 0.5362 \\
\hline & Ecosystem * Sex & 2.93 & 0.0243 \\
\hline \multirow{3}{*}{$\mathrm{Le} / \mathrm{Se}$} & Ecosystem & 4.95 & 0.0011 \\
\hline & Sex & 3.63 & 0.0598 \\
\hline & Ecosystem $*$ Sex & 0.22 & 0.9293 \\
\hline
\end{tabular}

$(\mathrm{Sc}+\mathrm{Sp}+\mathrm{Se}) /(3 \mathrm{Lb})-$ ratio of arithmetic mean value of the width of head, prothorax and elytra to body length; $\mathrm{Lp} / \mathrm{Sp}-\mathrm{ratio}$ of prothorax length to its maximum width; Le/Lp - ratio of elytra length to prothorax length; $\mathrm{Se} / \mathrm{Sp}$ - ratio of maximum width of elytra to maximum prothorax width; Sp2/Sp3 - ratio of prothorax width at the back edge to its maximum width; Le/Se - ratio of elytra length to their width.

gradient. The most constant morphometric index (Fig. 3) is the ratio of prothorax length to its maximum width $(\mathrm{Lp} / \mathrm{Sp})$.

After combination of all the measured individuals of $B$. varium into one sample and their distribution depending on body length (Fig. $4 a-4 m$ ), we found that the characteristics most closely associated with body size of the beetles are Le $\left(r^{2}=0.854\right), \operatorname{Se}\left(r^{2}=0.799\right), \mathrm{Lp}\left(r^{2}=0.723\right), \mathrm{Sc}\left(r^{2}\right.$ $=0.703), \mathrm{Sp} 1\left(\mathrm{r}^{2}=0.677\right), \mathrm{Sp} 2\left(\mathrm{r}^{2}=0.674\right)$ and $\mathrm{Sp} 3\left(\mathrm{r}^{2}\right.$ $=0.699)$. At the same time, none of the six considered morphometric indices (Fig. $4 n-4 s$ ) correlates with an increase in body size: $\mathrm{r}^{2}$ is in the range $0.002-0.038$.

\section{Discussion}

Changes in environmental factors affect size of insects (Dreyer and Shingleton, 2011). The nature of the substrate and the presence of vegetation largely determine the size and form of the body of ground beetles. This is especially true of ground beetles in hygrophilous biotopes, where habitat conditions are diverse and unstable. There is a relationship between body form and ecological characteristics of the habitats of species of the tribe Bembidiini (ANDERSEN, 1985). Body size data for $B$. varium is limited to total body length. It is known from sources in the literature that body length varies mainly within $3.0-6.5 \mathrm{~mm}$ (Table 4). In our research, the body length of individuals varies in the range of $4.17-5.25 \mathrm{~mm}$, averaging $4.75 \mathrm{~mm}$.

The ability of insects to fly is a key mechanism in the settlement of new biotopes. It is increasingly recognized that physiological and behavioural mechanisms control the flying ability of beetles (IVERSEN et al., 2017). Various authors indicate that $B$. varium is a macropterous species (Hurka, 1996; Matalin, 2003). Our study also confirms that fact.

The variability of half of the linear characteristics of $B$. varium (body length, head length and width, width of prothorax between front angles, its maximum width and elytra width) and two morphometric indices $((\mathrm{Sc}+\mathrm{Sp}+\mathrm{Se}) /$ (3Lb), Le/Se) are observed in the considered ecosystems. We suggest that soil salinization has the greatest impact on the variability of these parameters. However, the influence of other equally important environmental factors (food availability during the larval stage, rivalry, infectious disease and parasites, temperature and mechanical composition of soil and anthropogenic factors) is not excluded. The variability of these linear characteristics and morphometric indices in gradient of soil salinity was previously described by us for B. minimum (КомLYK and BrygadyrenKo, 2019b). Changes in the remaining body parameters are not significant, which makes them useless for biological indication of the habitat conditions of $B$. varium. The size of the back angles of the prothorax does 

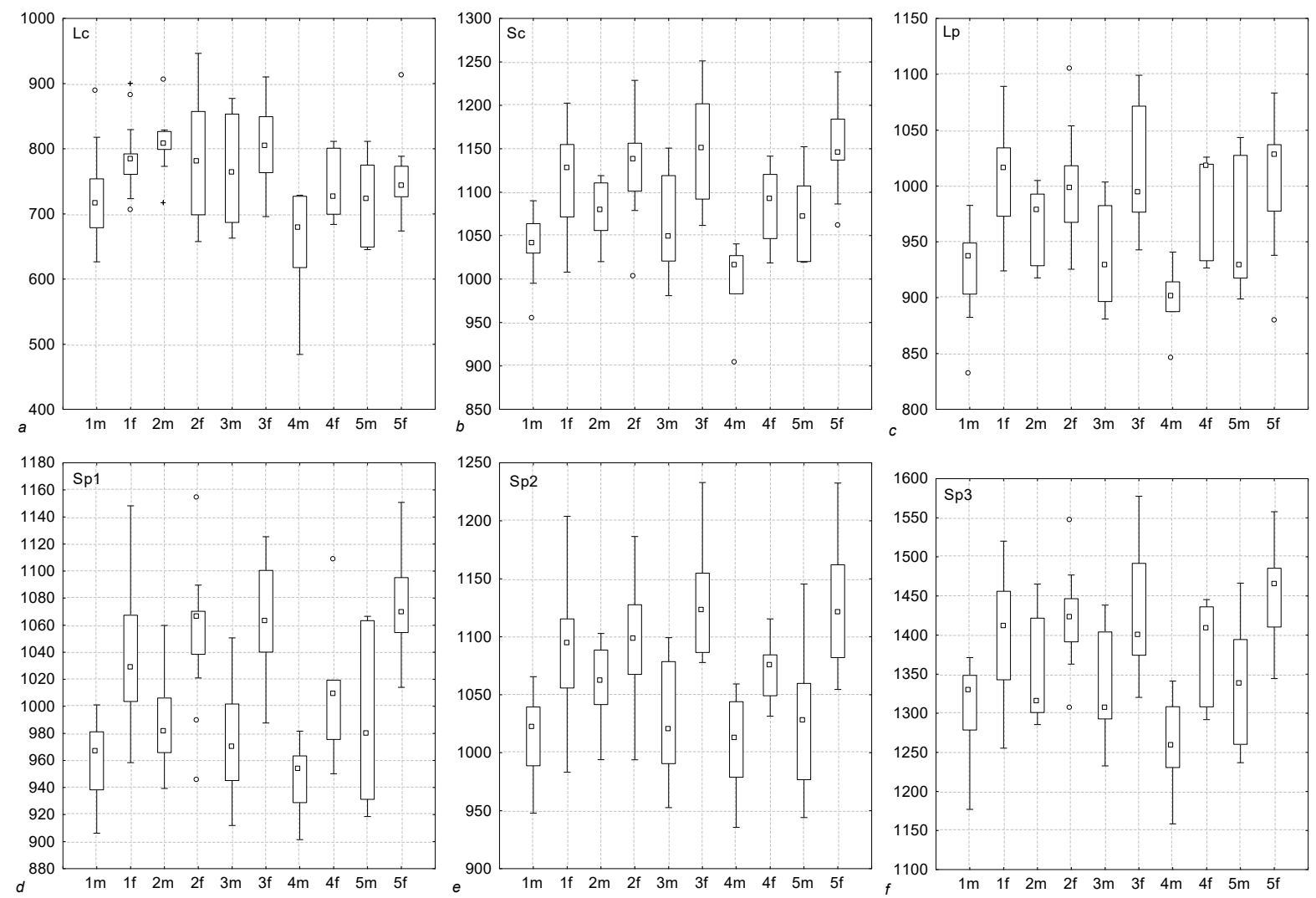

Fig. 1. Variability of morphometric characteristics of the head and prothorax of B. varium in the studied populations: for names of the characteristics see Table 2; the figure shows Box-Whisker plots with the whiskers indicating minimum and maximum, the box describing the range between first and third quartile, the square indicating the median and outliers shown by dots and crosses.
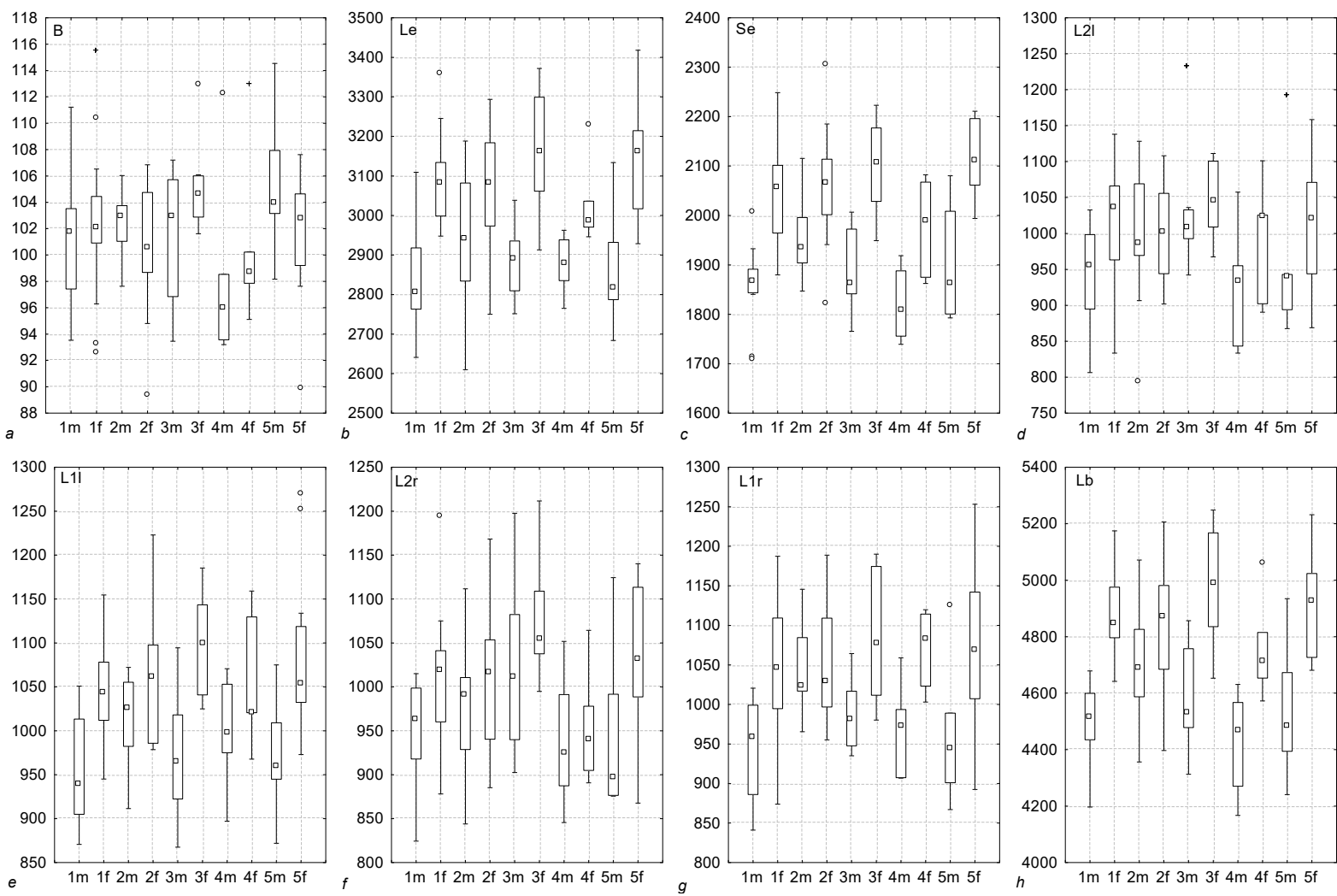

Fig. 2. Variability of the posterior angles of prothorax and morphometric characteristics of elytra of $B$. varium in the studied populations: for names of the characteristics see Table 2, Fig. 1. 

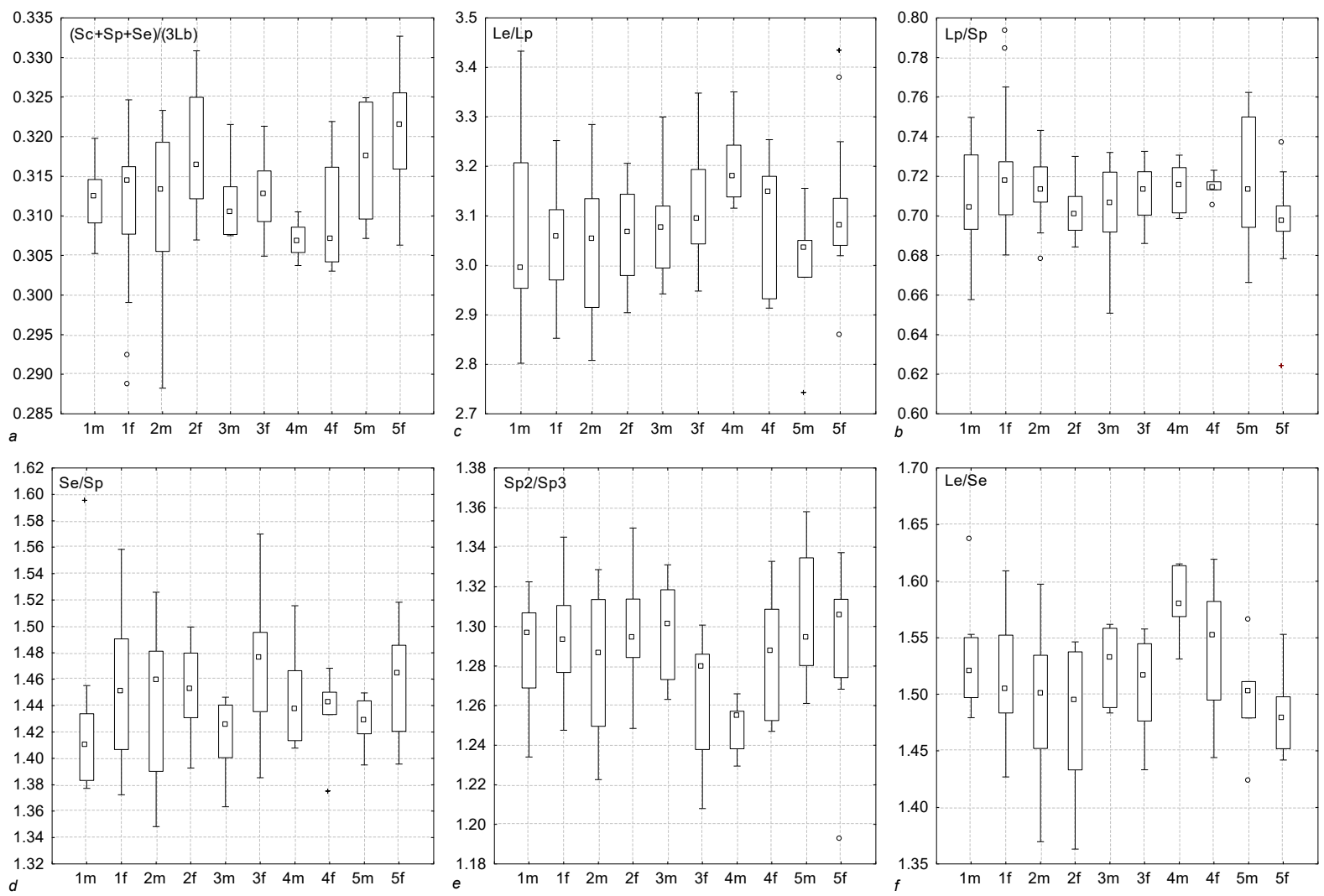

Fig. 3. Variability of morphometric indices of $B$. varium in the studied populations: for names of the characteristics see Fig. 2.

Table 4. Sizes of Bembidion varium from various sources

\begin{tabular}{ccc}
\hline Country & Size $(\mathrm{mm})$ & Source \\
\hline Armenia & $3.0-4.5$, usually $4.0-4.5$ & IABLOKOV-KHNZORYAN, 1976 \\
Great Britain & $4.1-5.1$ & LiNDROTH, 1974 \\
Egypt & $4.8-6.5$ & ABDEL-DAYEM, 1998 \\
Tatarstan & $3.8-5.0$ & ZHEREBTSOV, 2000 \\
Fennoscandia, Denmark & $4.1-5.1$ & LiNDROTH, 1985 \\
Czech Republic, Slovakia & $3.4-5.2(4.5)$ & HuRKA, 1996 \\
Ukraine & $4.17-5.25$, averaging 4.75 & This article \\
\hline
\end{tabular}

not change in the different ecosystems in $B$. varium unlike B. minimum (KOMLYK and BRYGADYRENKo, 2019b).

In most ground beetles, females are larger than males in most linear parameters (SUKHODOLSKAYA et al., 2016). In our studies females of $B$. varium are larger than males in all the considered linear parameters. Differences between males and females in size of the back angles of the prothorax are not significant. Similar data were obtained for other species of ground beetles of the genus Bembidion: B. articulatum (Panzer, 1796) (Brygadyrenko and SLYNKO, 2015), B. aspericolle (Germar, 1829) (KoMLYK and Brygadyrenko, 2019a), B. minimum (Komlyk and BRYGADYRENKO, 2019b). Differences between sexes in B. varium are not significant for all morphometric indices except $\mathrm{Se} / \mathrm{Sp}$. Females of $B$. varium have wider and longer elytra as in most species of ground beetles
(BRygadyrenko and ReshetNiak, 2016). However, females of B. articulatum (BRYGADYRENKO and SLYNKO, 2015), B. aspericolle (KomLYK and Brygadyrenko, 2019a), B. minimum (Komlyk and Brygadyrenko, $2019 b)$ are characterized by an isometric increase in body size, i.e. body proportions remain unchanged with a change in absolute size of beetles.

The increase in the salinity of the soil solution, as a determining environmental factor in the considered ecosystems does not cause changes in dimorphism between males and females for all linear measurements and morphometric indices; similarly no changes are recorded within the sex groups. The ratio of prothorax length to its maximum width is the most stable index for $B$. varium as for B. minimum (Komlyk and BRYGADYRENKO, 2019b), i.e. differences in the form of 

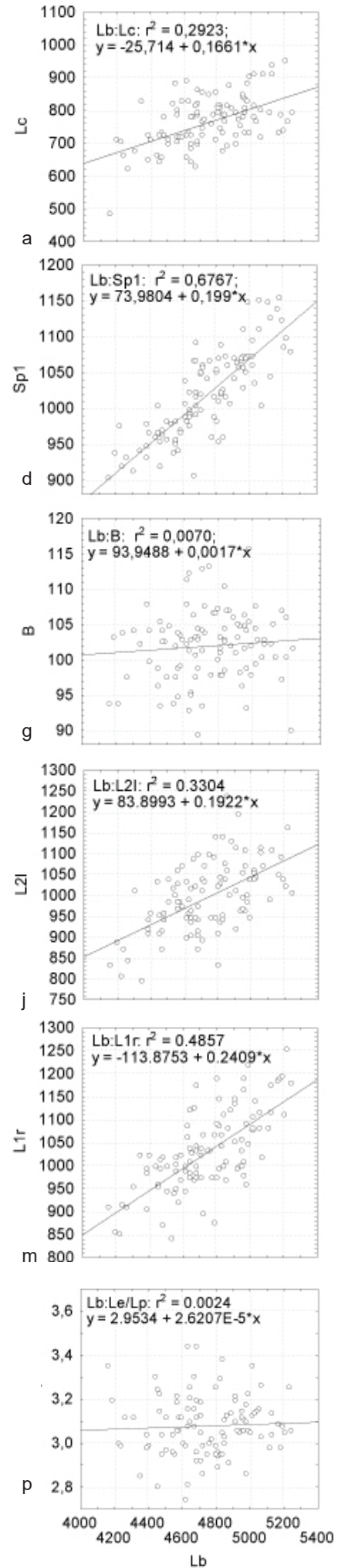

Lb
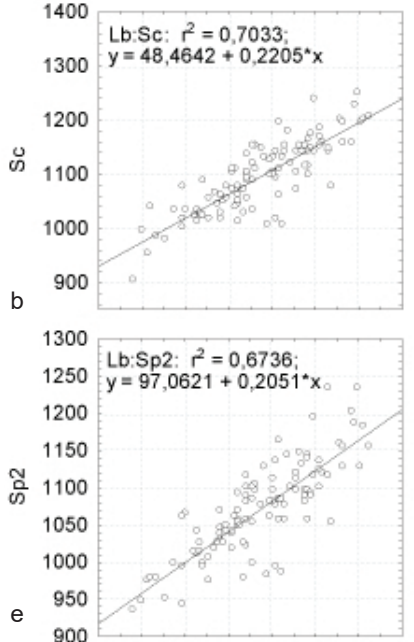

e 950

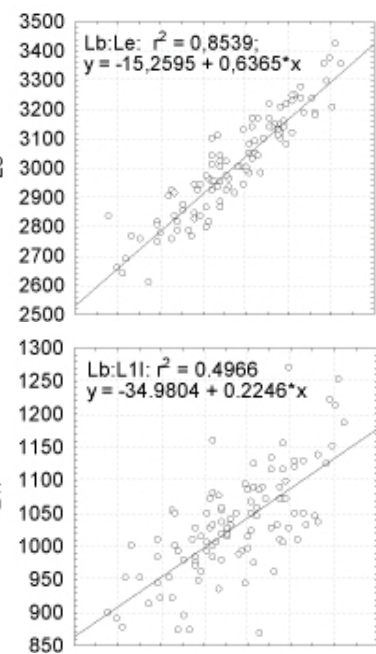

k 850
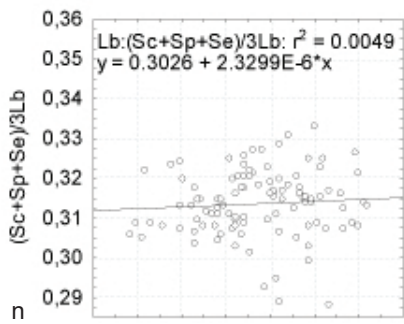

$n^{0,29}$

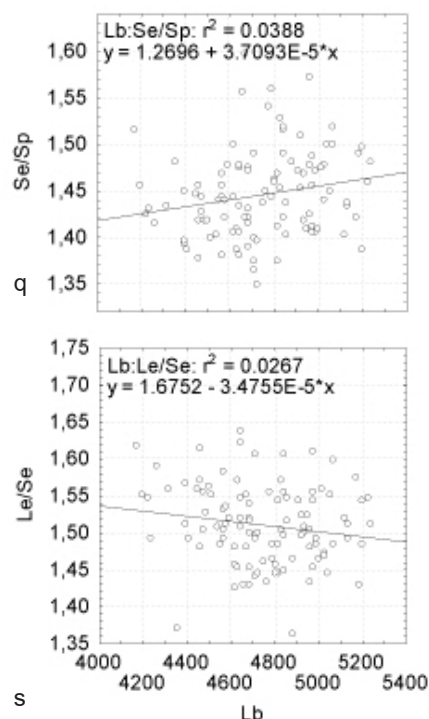

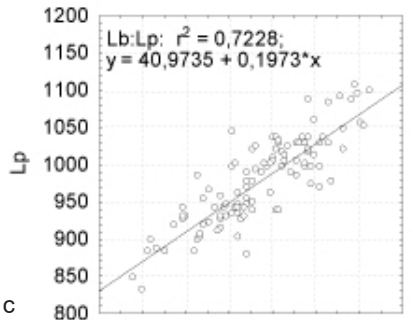

C 800

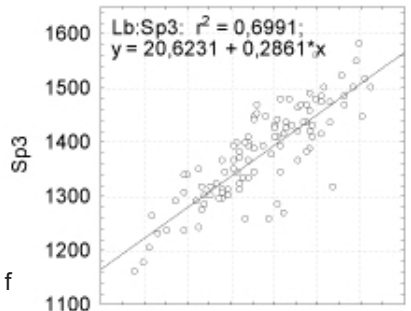

1100
2400

Lb:Se: $r^{2}=0,7996$ :

$2300 y=-211,8558+0,4644^{*} x$

2200

2100

(i) 2000

1900

1800

1700

1600

1250

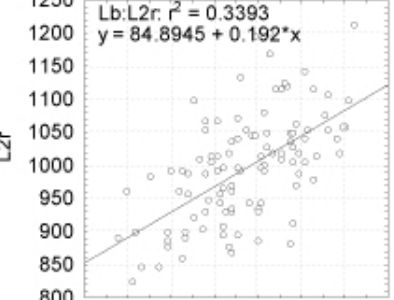

I 800
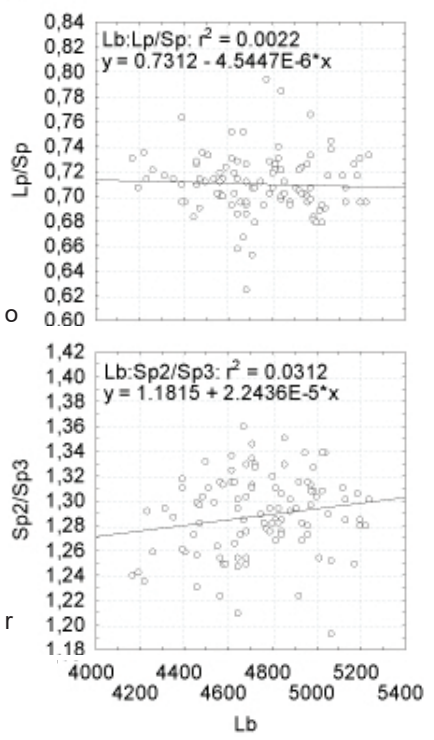

Fig. 4. Scatter diagram of morphometric characteristics and indices of males and females of $B$. varium depending on their body length: for names of characteristics and indices see Tables 2, 3 . 
prothorax between males and females are not significant. Bembidion varium is characterized by a close relationship between head width, prothorax length and width, elytra length and width, and total body length of the individuals.

\section{Conclusions}

Despite the existence of research on the morphological variability of ground beetles, it still remains unclear which of the environmental factors are determining and at what stages of ontogenesis their impact is more significant. The results presented in this research expand knowledge about the morphological variability of riparian ground beetles and support the hypothesis that certain environmental factors can influence some important morphometric characters of insects. This research is consistent with our previous research of B. minimum. The same linear characteristics and morphometric indices vary. Thus, we might conclude that the salinity is one of the environmental factors influencing the life history and population variability of the hygrophilous beetles. The results obtained suggest further study of this issue on the example of ground beetle species, which will help to further identify the causes and mechanisms of species stability in natural and anthropogenic transformed ecosystems.

\section{Acknowledgements}

The authors are sincerely grateful to the Editor and anonymous reviewers for their invaluable help in preparing the manuscript for publication. This study was supported by the Ministry of Education and Science of Ukraine (grant 0118U003303).

\section{References}

Abdel-Dayem, M.S., 1998. The Egyptian species of Bembidion Latreille, 1802 (Coleoptera, Carabidae). Bulletin of the Entomological Society of Egypt, 76: 181198.

Abdurakhmanov, G.M., NaKhibasheva, G.M., Klycheva, S.M., Magomedova, S.T., Elderhanova, Z.M., 2010. Vidovoy sostav i geograficheskoye rasprostraneniye zhuzhelits roda Bembidion Respubliki Dagestan [Species structure and geographical distribution of ground beetles of genus Bembidion of Daghestan Republic]. The South of Russia: Ecology, Development, 2: 56-61. doi:10.18470/1992-1098-2010-2-56-61

ANDERSEN, L., 1985. Ecomorphological adaptations of riparian Bembidini species (Coleoptera: Carabidae). Entomologia Generalis, 11: 41-46. doi:10.1127/entom. gen/11/1985/41

ARndT, E., Santamaria, S., 2004. Laboulbeniales (Ascomycota) of the Canary Islands. Vieraea, 32: 107 115 .

Atamenr, A., 2013. Ground beetles (Coleoptera: Carabidae) of Azerbaijan, Iran. Turkish Journal of Zoology, 37 (2): 188-194.

Bonal, R., Espelta, J.M., Vogler, A.P., 2011. Complex selection on life-history traits and the maintenance of variation in exaggerated rostrum length in acorn weevils. Oecologia, 167 (4): 1053-1061. doi:10.1007/s00442011-2036-7

BRYGADYRENKo, V.V., 2015a. Evaluation of the ecological niche of some abundant species of the subfamily Platyninae (Coleoptera, Carabidae) against the background of eight ecological factors. Folia Oecologica, 42 (2): 75-88.

Brygadyrenko, V.V., 2015b. Parameters of ecological niches of Badister, Licinus and Panagaeus (Coleoptera, Carabidae) species measured against eight ecological factors. Baltic Journal of Coleopterology, 15 (2): 137154.

BrygadyrenKo, V.V., 2016. Evaluation of ecological niches of abundant species of Poecilus and Pterostichus (Coleoptera: Carabidae) in forests of the steppe zone of Ukraine. Entomologica Fennica, 27 (2): 81-100.

Brygadyrenko, V.V., Korolev, O.V., 2015. Morphological polymorphism in an urban population of Pterostichus melanarius (Illiger, 1798) (Coleoptera, Carabidae). Graellsia, 71 (1): e025. http://dx.doi.org/10.3989/ graellsia.2015.v71.126

Brygadyrenko, V.V., Reshetniak, D.Y., 2016. Morphometric variability of Clitellocephalus ophoni (Eugregarinida, Gregarinidae) in the intestines of Harpalus rufipes (Coleoptera, Carabidae). Archives of Biological Sciences, 68 (3): 587-601. https://doi.org/10.2298/ABS150923049B

Brygadyrenko, V.V., Slynko, V.O., 2015. Morphological variability of Bembidion articulatum (Coleoptera, Carabidae) populations: linear dimensions depend on sex, while morphological indices depend on ecosystems. International Journal of Applied Environmental Sciences, 10: $163-187$.

Bukejs, A., Telnov, D., 2007. Materials about the fauna of beetles (Insecta: Coleoptera) of Naujene Rural Municipality (Daugavpils district, Latvia). Part 2. Acta Biologica Universitatis Daugavpiliensis, 7 (2): 191-208.

Clark, T.M., Flis, B. J., Remold, S.K., 2004. Differences in the effects of salinity on larval growth and developmental programs of a freshwater and a euryhaline mosquito species (Insecta: Diptera, Culicidae). Journal of Experimental Biology, 207: 2289-2295. doi:10.1242/ jeb. 01018

Dangalle, C.D., Pallewatta, N., Vogler, A.P., 2013. The association between body-size and habitat-type in tiger beetles (Coleoptera, Cicindelidae) of Sri Lanka. Ceylon Journal of Science (Biological Sciences), 42 (1): 41-53. doi:10.4038/cjsbs.v42i1.5898

Den Boer, P.J., 1970. On the significance of dispersal power for populations of carabid-beetles (Coleoptera, Carabidae). Oecologia, 4: 1-28.

Dreyer, A.P., Shingleton, A.W., 2011. The effect of genetic and environmental variation on genital size in male Drosophila: canalized but developmentally unstable. PLoS One, 6 (12): e28278. https:/doi.org/10.1371/journal. pone. 0028278

Elek, Z., Lovei, G.L., BatKi, M., 2014. No increase in fluctuating asymmetry in ground beetles (Carabidae) as urbanisation progresses. Community Ecology, 15 (2): 131-138. https://doi.org/10.1556/ComEc.15.2014.2.1

ERnsting, G., IsAaKs, J.A., 1997. Effects of temperature and season on egg size, hatchling size and adult size in Notiophilus biguttatus. Ecological Entomology, 22 (1): 32-40. https://doi.org/10.1046/j.1365-2311.1997.00040.x

Gueorguiev, B.V., 2007. Annotated catalogue of the carabid beetles of Albania (Coleoptera: Carabidae). SofiaMoscow: Pensoft. 247 p.

GuEORGUIEv, B., 2011. New and interesting records of carabid beetles from South-East Europe, South-West and Central 
Asia, with taxonomic notes on Pterostichini and Zabrini (Coleoptera, Carabidae). Linzer Biologische Beiträge, 43 (1): 501-547.

Gueorguiev, V.B., Gueorguiev, B.V., 1995. Catalogue of the ground-beetles of Bulgaria (Coleoptera: Carabidae). Sofia-Moscow: Pensoft. 279 p.

Hieke, F., Wrase, W., 1988. Faunistik der Laufkäfer Bulgariens (Coleoptera, Carabidae). Deutsche Entomologische Zeitschrift, 35: 1-171. doi:10.1002/mmnd.19880350102

Hristovski, S., Gueorguiev, B., 2015. Annotated catalogue of the carabid beetles of the Republic of Macedonia (Coleoptera: Carabidae). Zootaxa, 4002: 1-190. http:// dx.doi.org/ 10.11646/zootaxa.4002.1.1

Hurka, K., 1996. Carabidae of the Czech and Slovak Republics. Zlin: Kabourek. 565 p.

IABLOKOv-KhNZORYAN, S.M., 1976. Fauna Armyanskoy SSR. Zhuzhelitsy (Carabidae) [Ground beetles (Carabidae) of Armenian SSR]. Erevan: Izdatelstvo AN Armyanskoy SSR. 295 p.

Iversen, L.L., Rannap, R., Briggs, L., SAnd-Jensen, K., 2017. Time-restricted flight ability influences dispersal and colonization rates in a group of freshwater beetles. Ecology and Evolution, 7 (3): 824-830. https://doi. org/10.1002/ece 3.2680

Jocque, M., Teofilova, T.M., Kodzhabashev, N.D., 2016. Light trapping as a valuable rapid assessment method for ground beetles (Carabidae) in a Bulgarian wetland. Acta Zoologica Bulgarica, 68 (4): 529-539.

Kawano, K., 2006. Sexual dimorphism and the making of oversized male characters in beetles (Coleoptera). Annals of the Entomological Society of America, 99 (2): 327-341. https://doi.org/10.1603/0013-8746(2006)099[0327:sdatm o] $2.0 . \mathrm{co} ; 2$

KaWANO, K., 2016. Comparative quantification of intralocational, interlocational, and interspecific variability in stag beetles (Coleoptera: Lucanidae) and the questions of phenotypic plasticity and species selection. Annals of the Entomological Society of America, 109 (4): 555-566. https://doi.org/10.1093/aesa/saw011

KaZi, A.J., Khatri, I., Rustamani, M.A.,Wagan, M.S., 2016. Records of Carabidae in fauna of British India segregated for present boundaries of Pakistan. Sindh University Research Journal, 48 (4): 833-838.

Komlyk, V.O., Brygadyrenko, V.V., 2019a. Morphological variability of Bembidion aspericolle (Coleoptera, Carabidae) populations in conditions of anthropogenic impact. Biosystems Diversity, 27 (1): 21-25. https://doi. org/10.15421/011903

Komlyk, V.O., BRYGadyrenko, V.V., 2019b. Morphological variability of Bembidion minimum (Coleoptera, Carabidae) populations under the influence of natural and anthropogenic factors. Biosystems Diversity, 27 (3): 250-269. https://doi.org/10.15421/011935

KOPECKY, T., 2007. Biotopes of low stream of Orlice River (Czech Republic, Europe) with example of the typical ground beetles (Coleoptera: Carabidae). Elateridarium, 1: 77-91.

Kryzhanovskiu, O.L., Belousov, I.A., KabaK, I.I., Kataev, B.M., Makarov, K.V., Shilenkov, V.G., 1995. A checklist of the ground-beetles of Russia and adjacent lands. SofiaMoscow: Pensoft. 274 p.

Langraf, V., Petrovičová, K., David, S., Ábelová, M., Schlarmannoví, J., 2017. Body volume in ground beetles (Carabidae) reflects biotope disturbance. Folia Oecologica, 44 (2): 114-120. https://doi.org/10.1515/ foecol-2017-0014

Lindroth, C.H., 1974. Coleoptera, Carabidae. Handbooks for the identification of British insects, vol. 4, part 2. London: Royal Entomological Society of London. 148 p.
LindRoth, C.H., 1985. The Carabidae (Coleoptera) of Fennoscandia and Denmark. Fauna Entomologica Scandinavica, 15, 1. Leiden: Brill. 226 p.

Luff, M.L., 2007. The Carabidae (ground beetles) of Britain and Ireland. Handbooks for the identification of British insects, vol. 4, part 2. Shrewsbury: Field Studies Council. $247 \mathrm{p}$.

Lupi, D., Jucker, C., Rocco, A., Harrison, R., Colombo, M., 2015. Notes on biometric variability in invasive species: The case of Psacothea hilaris hilaris. Bulletin of Insectology, 68 (1): 135-145.

Martinková, Z., Koprdová, S., Kulfan, J., Zach, P., HonĚK, A. 2019. Ground beetles (Coleoptera: Carabidae) as predators of conifer seeds. Folia Oecologica, 46 (1): $37-$ 44. https://doi.org/10.2478/foecol-2019-0006

Martynov, V.O., Brygadyrenko, V.V., 2018. The impact of some inorganic substances on change in body mass of Tenebrio molitor (Coleoptera, Tenebrionidae) larvae in a laboratory experiment. Folia Oecologica, 45 (1): 24-32. https://doi.org/10.2478/foecol-2018-0003

Matalin, A.V., 1998. Influence of weather conditions on migratory activity of ground beetles (Coleoptera, Carabidae) in the Steppe Zone. Biology Bulletin, 25 (5): 485-494.

Matalin, A.V., 2003. Variations in flight ability with sex and age in ground beetles (Coleoptera, Carabidae) of SouthWestern Moldova. Pedobiologia, 47 (4): 311-319. https:// doi.org/10.1078/0031-4056-00195

OkuZaki, Y., Sota, T., 2018. Predator size divergence depends on community context. Ecology Letters, 21 (7): 1097-1107. https://doi.org/10.1111/ele.12976

PALMER, M., 2002. Landmark-based morphometric analysis of two sibling species of the genus Asida (Coleoptera, Tenebrionidae). Contributions to Zoology, 70 (4): 213220.

Petillon, J., Georges, A., Canard, A., Ysnel, F., 2007. Impact of cutting and sheep grazing on ground - active spiders and carabids in intertidal salt marshes (Western France). Animal Biodiversity and Conservation, 30 (2): 201-209.

Pichu, R., 2016. Soil salinization. Oxford research encyclopedias. Environmental science. Oxford: Oxford University Press. [cit. 2019-11-12]. https://oxfordre.com/environmentalscience/ view/10.1093/acrefore/9780199389414.001.0001/ acrefore-9780199389414-e-65?rskey $=$ dgQ8AZ\&result=64

Pie, M.R., Traniello, J.F.A., 2007. Morphological evolution in a hyperdiverse clade: the ant genus Pheidole. Journal of Zoology, 271 (1): 99-109. https://doi.org/10.1111/j.14697998.2006.00239.x

Putchкov, A.V., 2012. Faunisticheskiy obzor karaboidnykh zhukov (Coleoptera, Caraboidea) Ukrainy [A review of the caraboids-beetles (Coleoptera, Caraboidea) of Ukraine]. Ukrayinskiy Entomologichniy Zhurnal, 2 (5): 3-44.

Schultz, R., 2000. Ground beetles (Coleoptera: Carabidae) as indicators for the efficiency of the revitalization of salt grassland at the Baltic Sea coast. Mitteilungen der Deutschen Gesellschaft für Allgemeine und Angewandte Entomologie, 12 (1-6): 389-394.

Slinko, V.O., Brygadyrenko, V.V., Pakhomov, O.Y., 2008. Morfologicheskaya izmenchivost Bembidion varium (Carabidae, Coleoptera) v usloviyakh antropogennogo vozdejstviya [Morphological variability of Bembidion varium (Carabidae, Coleoptera) in the conditions of anthropogenic pressure]. Proceedings of the National Academy of Sciences of Azerbaijan (Biological Sciences), 64 (5-6): 200-206. 
Sowa, G., SkALSKI, T., 2019. Effects of chronic metal exposure on the morphology of beetles species representing different ecological niches. Bulletin of Environmental Contamination and Toxicology, 102 (2): 191-197. https:// doi.org/10.1007/s00128-018-02532-7

Spomer, S.M., Brewer, G.J., Fritz, M.I., Harms, R.R., Klatt, K.A., Johns, A.M., Crosier, S.A., Palmer, J.A., 2015. Determining optimum soil type and salinity for rearing the federally endangered salt creek tiger beetle, Cicindela (Ellipsoptera) nevadica lincolniana Casey (Coleoptera: Carabidae: Cicindelinae). Journal of the Kansas Entomological Society, 88 (4): 444-449. https:// doi.org/10.2317/0022-8567-88.4.444

SuKhodolskaya, R., SAVEliev A., 2016. Intra-specific body size variation of ground beetles (Coleoptera: Carabidae) in latitudinal gradient. Periodicum Biologorum, 118 (3): 273-280. https://doi:10.18054/pb.2016.118.3.3918

Sukhodolskaya, R.A., Saveliev, A.A., Muhammetnabiev, T.R., 2016. Sexual dimorphism of insects and conditions of its manifestation. Research Journal of Pharmaceutical, Biological and Chemical Sciences, 7 (2): 1992-2001.

Szentkiralyi, F., Bernath, B., Kadar, F., Retezar, I.,
2005. Flight of ground beetles towards polarized and unpolarized light sources. DIAS Report, 114: 313-324.

Tamutis, V., TAmutel, B., Ferenca, R., 2011. A catalogue of Lithuanian beetles (Insecta, Coleoptera). Zookeys, 121: 1-494. https://doi.org/10.3897/zookeys.121.732

TuRIN, H., 2000. De Nederlandse loopkevers - verspreiding en oecologie (Coleoptera: Carabidae) [Ground beetles of the Netherlands - distribution and ecology (Coleoptera: Carabidae)]. Nederlandse fauna, 3. Leiden: Nationaal Natuurhistorisch Museum Naturalis, KNNV Uitgeverij \& EIS Nederland. $666 \mathrm{p}$.

Vician, V., Kočík, K., Slobodník, B., Svitok, M., Stašıov, S., 2018. Carabid communities (Coleoptera, Carabidae) in differently managed forage legume stands in the Podpol'anie region (Central Slovakia). Folia Oecologica, 45 (2): 102-110. https://doi.org/10.2478/foecol-2018-0011

ZhereBTSOv, A.K., 2000. Opredelitel zhuzhelits Respubliki Tatarstan [Key to ground beetles of the Republic of Tatarstan]. Kazan: Institut Ekologii Prirodnykh Sistem AN RT. 74 p.

Received December 2, 2019 Accepted March 4, 2020 